\title{
Having fun seriously matters: A visual arts-based narrative of methodological inventiveness
}

\section{Marguerite Müller}

School of Education Studies, Education, University of the Free State, Bloemfontein, South Africa mullerm@ufs.ac.za

https://orcid.org/0000-0002-7620-470X

(Received: 13 September 2019; accepted: 27 January 2020)

\section{Abstract}

My purpose in this article is to explore what methodological inventiveness has made possible for me as a selfreflexive researcher. As South African educational researchers, we need to consider how a better understanding of our own experiences, identities, and subjectivities correspond with a context of rapid change, transformation, and decolonisation. Within this understanding it is useful to think of methodological inventiveness as a form of post qualitative inquiry that embraces the possibilities of different educational methodologies to open up and resist pre-determined and formulaic ways of doing and knowing. Through a playful engagement with the children's book Zog (Donaldson \& Scheffler, 2010) I create an arts-based narrative to show how my journey of becoming an educational researcher unfolds. I use playfulness and joy to show how methodological inventiveness makes it possible for me, as a self-reflexive researcher, to engage with fluid and complex identities and contextual realities.

Keywords: methodological inventiveness, arts-based inquiry, self-reflexive methodologies, post-qualitative inquiry, joy

\section{The benefit of the not-knowing}

I did not to know much about educational research methodologies when I entered my postgraduate studies. A lack of knowledge is not something one would usually highlight as an asset in academic circles but looking back I realise that not knowing helped me know differently. I came to the field of education with the mind and training of a fine artist, and, at first, I felt like a traveller who had arrived in a foreign country. My undergraduate studies had exposed me to post-structural scholars and theories that still linger in my understanding of research. The education I had received in the arts prepared me to connect intuition, senses, emotions, and theory in order to create art. However, when I first encountered qualitative educational research methodologies in my post-graduate studies, I did not immediately make the connection between doing research and creating art. I felt as though I were a tourist in a 
distant land, doing all the wrong things, making blunders, and struggling to communicate. I tried to read all the prescribed textbooks on qualitative educational methodologies, and eventually stumbled upon something that seemed to resonate with my way of thinking about the world-narrative inquiry. By using narrative methods, I began to see a path that led towards arts-based, collaborative, and self-reflexive methods. Slowly and with much uncertainty I found myself expanding a limited understanding of qualitative methods so that it could grow into something more familiar. When educational research methodologies started to make aesthetic sense to me, and when it started to look like an art form, I found myself full of joy and excited about doing research. In this paper, I explore how my journey with methodological inventiveness unfolded by focusing on the moments of discovery and joy that guided me along the way. In the next section, I consider the value of methodological inventiveness in my specific context.

\section{Responding to change in novel and inventive ways}

As South African educators, we work in a context of constant change. Within this context we are required to think on our feet and adapt daily to new challenges inside and outside the classroom. Think, for example, of the Fees Must Fall student movements. During the course of 2015 and 2016 South Africa was rocked by large scale student protest movements that demanded free tertiary education for all. The movements led to greater pressure being put on the national government to provide free tertiary education to students who could not afford tuition fees. Fees Must Fall also emphasised a call for decolonisation of South African higher education institutions (Jansen, 2017; Mbembe, 2016). One of the consequences of this was that we, as educators, had to consider how a better understanding of our own experiences, and identities, might be relevant in working towards a decolonised curriculum (Müller, Motai, Nkopane, Mofokeng, Lephatsoe \& Mouton, 2018). Fees Must Fall highlighted the need to revise and revisit continually our curriculum and pedagogy so that it remains responsive to the needs of the students and relevant in the current context. However, the change that is needed cannot stop at pedagogical or curriculum changes only.

Change requires us to respond in novel and inventive ways. Our research methods should echo our unique and novel responses. Yet, responding differently to new and novel questions might mean that we do not always know exactly what to do, or how to do it. As St Pierre aptly asked, "Why do we think we should know what to do before we begin to inquire?" (2019, p. 4). For St Pierre there is a distinct difference between inquiry and methodology. In writing about post-qualitative inquiry, she emphasised that the goal is not to represent, but rather to experiment and create new and novel ways of doing and knowing. When we work with post-qualitative inquiry words like data and analysis become problematic because of the implicit assumptions of representational logic on which they rely. Post-qualitative inquiry is strongly influenced by post-structural theories that resist the ontological assumption of a real world out there that can be in any way represented in research (St. Pierre 2019). I think of methodological inventiveness as a form of post-qualitative inquiry because it embraces the possibilities that different educational methodologies might open up but resists predetermined and formulaic ways of doing and knowing. 
Post-qualitative inquiry, thus, makes it possible to look for new ways to respond, through research, to our unique and ever-changing context. It helps us to engage with our notknowing in order to move towards new ways of knowing. Through a process of methodological inventiveness, I came to see educational research methodology as a form of art (instead of a recipe), and this understanding opened up new avenues in which to explore difficult issues. In my PhD study I wanted to explore educator identity during a time of change and transformation in the South African higher education context. During the research process I resisted pre-determined ways of doing a qualitative study and opted to have a more organic unfolding of discovery occur. In this article, I reflect on my journey of discovering the flow between subjectivity, methodology, and self-reflexivity through a visual narrative that unfolds in difficult, messy, and sometimes volatile educational spaces. The visual narrative can be seen as situated within an arts-based inquiry that draws on memory (Mitchell, Strong-Wilson, Pithouse, \& Allnutt, 2011), fiction (Clough 2002; Leavy 2013), poetry (Leavy, 2009) and imagination to create a performative (Denzin, 2003) and postqualitative (le Grange 2018, St. Pierre 2019) in which I explore possibilities for being and doing differently.

My aim is to explore how a creative engagement with methodology can create productive possibilities to respond to stifling and regulating new-liberal performance regimes of research. The visual narrative responds to the dynamic and fluid nature of professional and personal development as embedded in reflective practice and creative expression. Through this, following Gannon et al. (2019), I hope to highlight the joy, and playful possibilities of self-reflexive research methodologies that have helped me develop and grow as a researcher, an educator, and an artist. Thus, in this article, methodological inventiveness is understood as a form of inquiry, an organic, ever-changing, and intuitive response to growth and change in an educational environment of change and transformation. In the next section I draw on a fictional character called Zog to assist me in narrating my journey with methodological inventiveness in educational research.

\section{My research journey with a dragon called Zog}

I find much joy in reading bedtime stories to my children. What I love most about children's books is that they often tackle complex theoretical and philosophical issues in a very digestible, accessible, playful, and aesthetic way. The visual narratives make it possible to speak about complex issues yet keep us (young and old) glued to the beautiful pages. I have become interested in how we may use this technique in writing about educational research. Here I use children's literature to construct a visual narrative trough in which I "reflect on fictionalisation, both as a method of inquiry and as a literary practice in reporting research" (Eliastam, Müller, Müller, \& Trahar 2019, p. 12). I specifically chose the popular children's book Zog (Donaldson \& Scheffler, 2010) to communicate my understanding of methodological inventiveness and how it might possibly enrich research practice. According to Lawrence, "using the arts to present research findings makes the research accessible to a wider audience. Reading and writing fiction is one way that researchers can incorporate the arts into inquiry" (2019, p. 110). Lawrence collected and analysed data by creating imagined 
dialogues with fictional characters "to promote dialogue in education settings" (p. 123). Similarly, I use the fictional character Zog, created by Donaldson and Sheffler (2010), to help me share my experiences of methodological inventiveness in educational research.

\section{Learning how to ...}

Madam Dragon ran a school, many moons ago. She taught young dragons all the things that dragons need to know. Zog, the biggest dragon, was the keenest one by far. He tried his hardest every day to win a golden star. (Donaldson \& Scheffler, 2010, pp. $1-2)$

Zog is a dragon who goes to school to learn everything that dragons need to know. In the same way, I entered my postgraduate studies in order to learn everything I needed to know as an educational researcher. However, both Zog and I encountered significant challenges on our educational journeys.

In his first year of school Zog must learn how to fly.

All the dragons in year one were learning how to fly. 'High!' said Madam Dragon. 'Way up in the sky! .. . Zog went off to practice, flying fast and free. He soared and swooped and looped the loop ... then crashed into a tree. (pp. 3-4)

Just like Zog, I crashed into the tree, before I even knew I was doing research. My research journey started in a classroom where I was a relatively young and inexperienced teacher. I describe this moment in my $\mathrm{PhD}$ dissertation.

I suppose all stories have a beginning. This one began one Tuesday morning in a very dirty and chaotic high school art room in Pietermaritzburg, KwaZulu-Natal. I was sitting there watching things unfold and feeling utterly defeated and helpless. The room was swarming with grade nine Arts and Culture learners who were supposed to be doing a painting project, but the whole thing had spun totally out of control and now paint was flying through the air and colliding with grade nine bodies. Realising that I had lost control of the situation I sat down on my chair and tried to fight a raising panic and resist the urge to scream. What was I doing here? (Müller, 2016, p. 1)

I chose this extract from my dissertation to illustrate the way in which a specific difficult experience helped me start a journey as an educational researcher. In that grade nine Creative Arts classroom I found myself, much like Zog, overwhelmed by the task ahead. Botha and Rens refer to this feeling of dissonance as "reality shock" $(2018$, p. 1) which is commonly experienced by beginner teachers. 


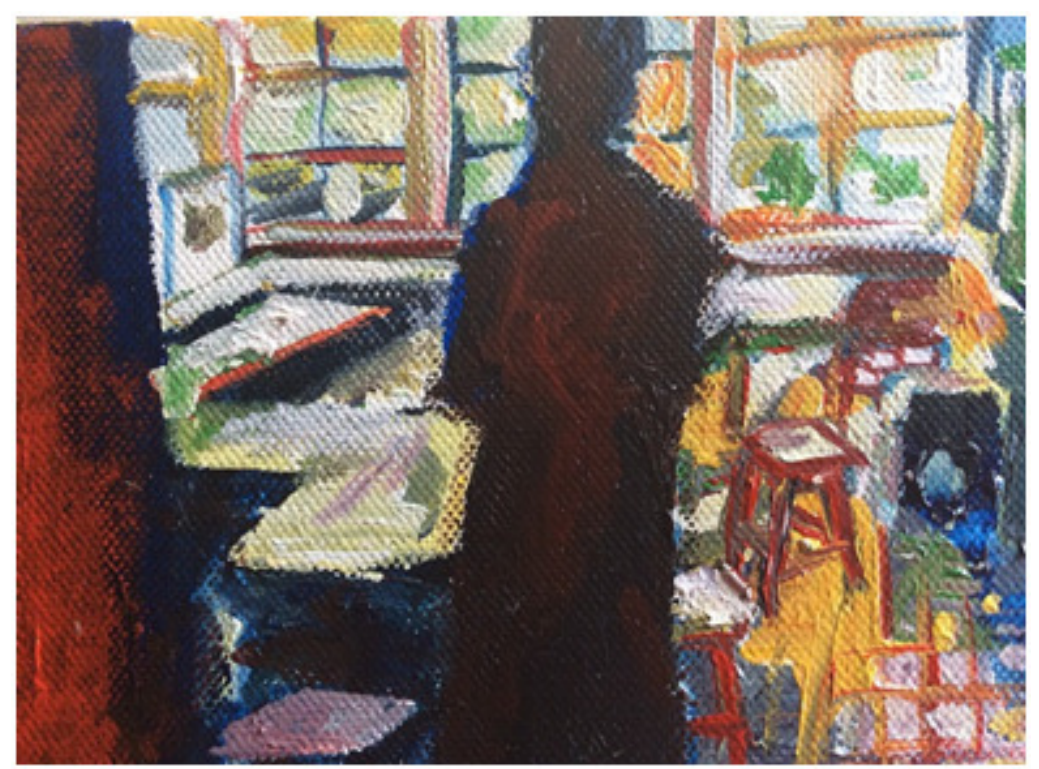

Figure 1: In a messy art room, Marguerite Müller, 2013, oil on canvas

After Zog crashes into the tree he is helped by a little girl. "Just then, a little girl came by. 'Oh, please don't cry' she said. 'Perhaps you'd like a nice sticky plaster for your head?'” (Donaldson \& Scheffler, 2010, pp. 5-6). Zog feels much better and he flies off "zigzagging through the blue" (p. 6). What helped me recover from my praxis shock was to write and draw about what had happened in the classroom and paint a picture of it. A reflective practice of writing, drawing, and painting became like that "plaster" for me; it was, and still is, my coping mechanism. By writing about what was happening in class each day I felt more in control of the situation. By painting myself into the classroom space I felt a sense of connection to and belonging in my new role. The experience I had was that I could write and paint myself in and out of difficult situations. Putting the chaos on paper made it seem more manageable. Later, when I read about writing as a method of inquiry (Richardson \& St.

Pierre, 2005) and arts-based research inquiry (Leavy, 2009) I realised my coping mechanism or plaster was actually a legitimate research method. I learned to use writings, drawings, and paintings to construct research texts. My understanding of what data and analysis are stems largely from the work of Richardson and St. Pierre who said that "writing is thinking, writing is analysis, writing is indeed a seductive and tangled method of discovery" (2005, p. 967). Writing, painting, and drawing became methods of discovery that helped me make sense of what was happening around me, what was happening to me, and what was happening inside of me. Although, I did not formally use the things I produced as research material until much later, I had a sense that the creative process was helping me move forward.

The intuitive feeling I had about creative engagement with lived experiences informed the methodologies in which I became interested as a researcher. One such method is self-studya method to engage with practice in a way that connects "the ontology and epistemology of pedagogy, in that I scrutinise my own "being" as a teacher in order to transform what and how I know and vice versa" (Knowles 2014, p. 91). Pithouse, Mitchell, and Moletsane explored "how inquiry into the self might illuminate significant social questions and make a qualitative difference to the shared human experience" (2009, p. 2). Furthermore, Meskin and 
Van der Walt have concluded that self-study thereby "offers a home in which we can explore our practice in a way that recognises the complexity of ourselves and create space for interrogating how that complexity drives our pedagogic and creative experience" $(2014,56)$. In learning about self-study as a research method I began to recognise myself as a legitimate participant in the research process. In a sense, the start of my methodological journey in education helped me to realise how much I did not know about myself.

\section{When to roar and when to listen}

A year went by and in Year Two the dragons learned to roar. "More!" said Madam Dragon. "Louder, I implore!" (Donaldson \& Scheffler, 2010, p. 7)

Learning about self-study and self-reflexive research methodologies helped me realise that my own experiences were important in the research journey. For me, the next phase was learning how to communicate these experiences in an impactful and meaningful way. Just as Zog was learning how to roar, I wanted to learn how to write research texts that could be published as academic work, and, at the same time, transcend academic traditions that exclude creative and aesthetic work. I encountered the work of narrative researchers like Clandinin and Connelly who expressed their approach to educational research thus: "We see teaching and teacher knowledge as expressions of embodied individual and social stories, and we think narratively as we enter into research relationships with teachers, create field texts and write storied accounts of educational lives" (2000, p. 4). Furthermore, Chase (2011) described narrative inquiry as research that is focused on life experiences, and as told by those who lived them. Narrative inquiry (Clandinin \& Connelly 2000; Chase 2011) helped me make connections between life experiences and educational research, but it also showed me how to communicate these in an academic tradition. As I began to communicate and share my own experiences with education, I realised that this was not a simple task. When we bring ourselves into the research story, we become vulnerable (Butler, 2004; Knowles, 2014) and I often felt alone and lost in the story I was trying to tell. The question of "What was I doing here?" (Müller, 2016, p. 1) and "Who am I?" (Young, 2007, p. 9) stayed with me throughout the process. 


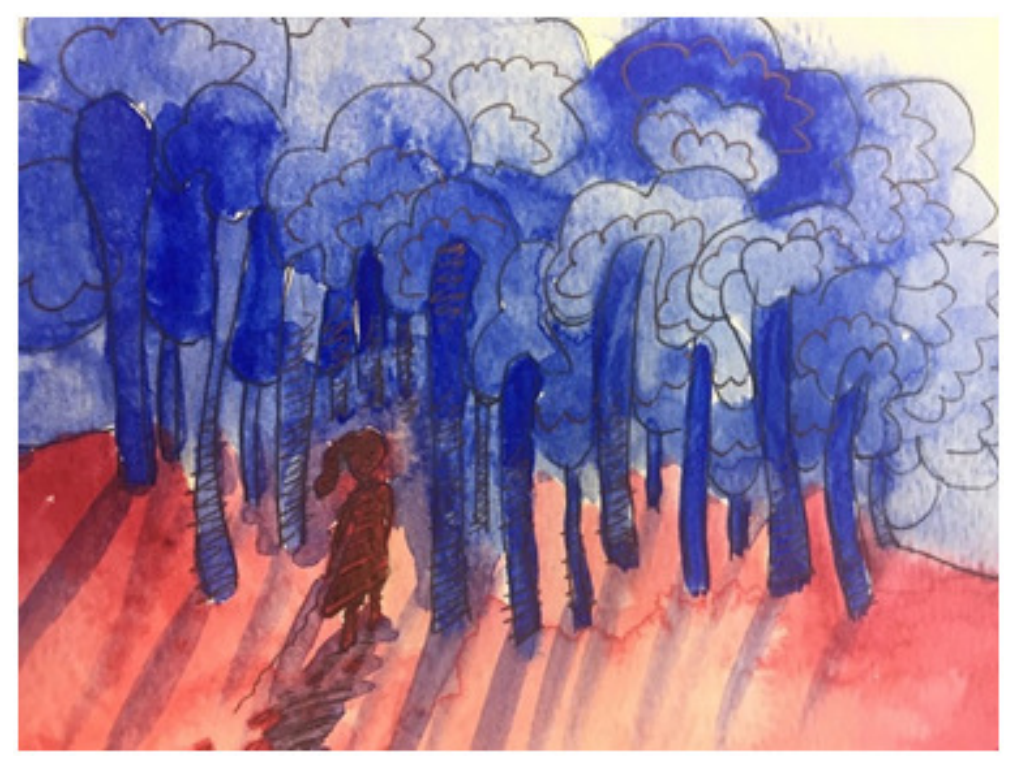

Figure 2: Getting lost is good research, Marguerite Müller, 2014, pen and watercolour on paper

I got lost countless times in my attempt to do self-study and narrative research. It was only when my story started to connect to that of others, and they became my critical friends (Franzak, 2002) that I was able to move forward. The interaction with participants in my PhD study showed me how useful formal collaborative reflection is in shaping reflective practice. Talking with others about their experiences helped me understand my own experiences differently. Ingold has reminded us that "people grow in knowledge not only through direct encounters with others, but also through hearing their stories told" (2011, pp. 160-161). I learned that it was sometimes good not to know where the story was going, and also that listening to others' stories could sometimes help me find a new path. I had learned that telling my story meant listening to the stories of others. Thus, I learned that participatory and collaborative approaches to narrative inquiry were crucial for creating rich and authentic research texts that could correspond with the context in which I work.

\section{What art makes possible}

For Zog, the next step was to learn how to breathe fire. "“No!' said Madam Dragon. 'Breathe out fire, not snow!'” (Donaldson \& Scheffler, 2010, p. 11).

I wish to draw attention specifically to being attuned to joy and positive affect (Gannon, et al., 2019) in methodological inventiveness. The research methods I am drawn to are those that bring me into an affective relationship with the research; in other words these are methods that keep me breathing "fire," not "snow." I like writing poems, I like reading stories, I like creating imaginary worlds, and I enjoy drawing and painting. Using the things that I enjoy makes it easier to feel excited about my research, but it also helps me to stay connected to what I am busy with. Just as Zog had to learn how to breathe fire, I had to learn how to find and use the research methods that I enjoy. This might seem obvious and easy, yet it is not in an academic environment that is influenced by "neoliberal ideologies, marketization and performative regimes" (Gannon, et al., 2019, p. 48). As creative researchers who want to pursue different ways of knowing, we often find ourselves having to 
defend our methods since they are measured against their more established and well-known qualitative cousins. As Zog tried to breathe out fire "his wing tip caught alight" (Donaldson $\&$ Scheffler, 2010, p. 12). I have found that methodological inventiveness requires you to leave the known, tried-and-trusted methods behind and search actively for new pathways that might not always be easy to follow. However, following St. Pierre (2019), I have also experienced that a desire to create new and novel ways of doing and knowing helps me find joy, not just in the process, but in building on the unexpected connections it makes possible.

Zog's next challenge was to capture a princess. "Zog went off to practice. He tried and tried and tried. But he simply couldn't manage. 'I'm no good at this,' he cried" (Donaldson \& Scheffler, 2010, p. 17). Like many of us, Zog felt defeated and uncertain of his ability to do what was required of him. But luckily the princess helped him out. "'Perhaps,' she said, 'you'd like to capture me? I'm Princess Pearl'” (p. 18). What I learn from the story of Zog is that we should resist the temptation to capture or be captured by a method of research. Manning (2016) warned us that method is "an apparatus of capture" (Manning, cited in St Pierre, 2019, p. 3 ). So instead of capturing or being captured we might seek, rather, a reciprocal relationship between the researcher and the research method in which both are willing to change a little in order to move forward. For example, in deciding to use arts-based inquiry for my $\mathrm{PhD}$ study I really struggled to move from thinking like an artist to thinking like an arts-based researcher. I found myself struggling with a desire to create artworks about the participants instead of creating artworks with the participants.

Richards and Haberlin (2019) have written about the tension that creative individuals might experience when they embark on using arts-based research. According to them, the challenge for the artist-turned-arts-based-researcher is that you have to learn to communicate the art practice as a form of inquiry. Barone and Eisner have pointed out that you must purposefully use "certain aesthetic qualities or design elements that infuse the inquiry process and the research text" (cited in Richards \& Haberlin 2019, p. 1942).

In learning how to become an arts-based researcher I had to abandon much of the initial drawing and painting I produced for my $\mathrm{PhD}$. For example, in figure 3 I share such a discarded painting. I created it after an interview with a participant to try to make sense of what she had told me, but in the drawing I found it hard to see her. It was as if she was spinning around in circles as I stood small and helpless at the side of her story. 


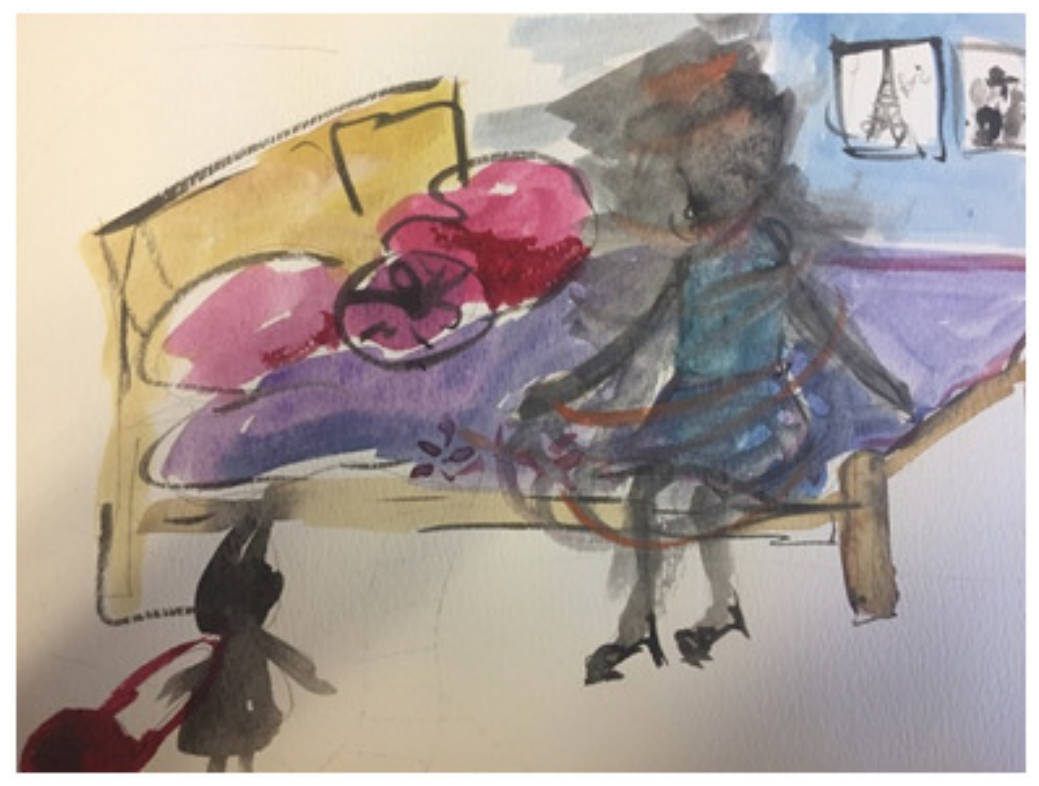

Figure 3: Discarded, Marguerite Müller, 2014, pen and watercolour on paper

I learned that the focus for the arts-based researcher is not on the artwork itself, nor on the meaning behind the artwork, but is, rather, on what the artwork makes possible. I turned to the use of collage and incorporated images brought by the participant and combined them with my own. Lahman et al. (2019) have written about the use of Collage Inquiry and use a collective collage poem to express their experiences.

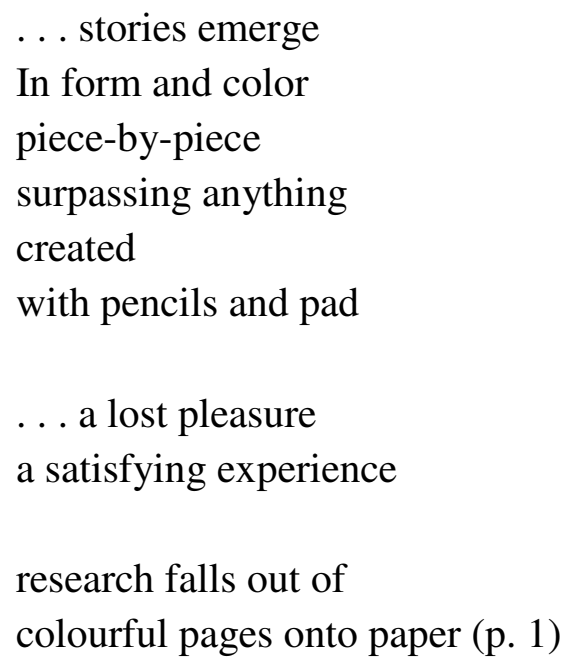

Through the use of collage, I was able to create artworks that focused more on listening to the participant, and less on making or telling (representing). 


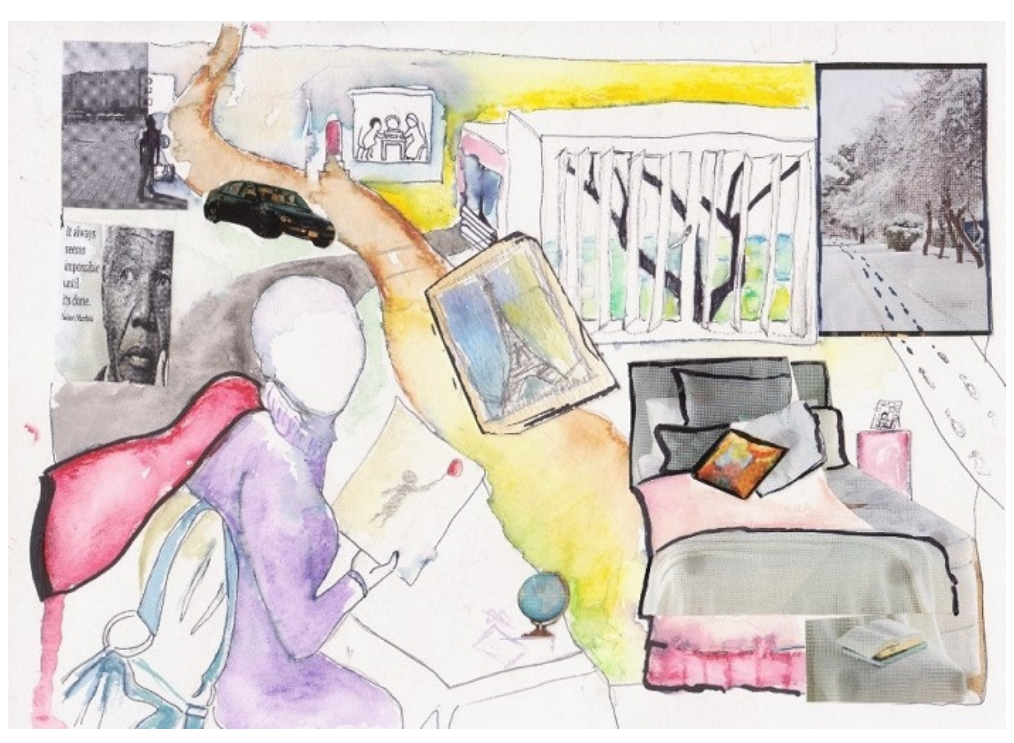

Figure 4: A portrait of Celine, Marguerite Müller, 2015, collage

\section{Knowing in a new way}

In his final year of school, Zog has to fight a real live knight. Zog and the knight get into an argument about who will save Princess Pearl, but she interrupts their fight.

STOP, you silly chumps! The world is already far too full of cuts and burns and bumps. Don't rescue me! I won't go back to being a princess. And prancing about the palace in a silly frilly dress. I want to be a doctor, and travel here and there. Listening to people's chests and giving them my care. (p. 24)

In one short statement Pearl gives Zog and the knight a lesson in feminism and the transformative paradigm. She also changes the course of the expected narrative outcome of a dragon, princess, and knight triangle by suggesting they should rather work together to care for others.

I think of Princess Pearl as a metaphor for methodological inventiveness since she helps to connect the theory (the knight) with the researcher (Zog) in order to work towards transformative outcomes. On my research journey I have realised that theory has to come alive through methodology, and that methodology informs theory. The purpose of methodological inventiveness is to create ways in which we can do educational research that enables us to respond to a rapidly changing education context. The joy and the fun of creation does not have to undermine the seriousness of the issues with which we deal in research on transformation and social change. In fact, joy and playfulness might make it possible to do research that pushes the boundaries of what we imagine the limits to be. Creative processes of knowledge production have for long been seen as inferior in the hierarchical understanding of what constitutes serious and scientific thought, and Gannon and Gonick (2019) have argued that it is precisely for this reason that feminist approaches to research must include creative and collaborative methods that resist regulatory research traditions. Thus, I understand methodological inventiveness as a joyful (feminist) resistance to systems that might stifle and regulate us since it allows new pathways to emerge. Furthermore, as Pithouse-Morgan, Coia, 
Taylor, and Samaras have written, "when hope and optimism are supported by experiential wisdom gained through shared creative engagement, we can confidently make a qualitative difference in our work with students and colleagues, and more broadly at the level of programs and policy" (2016, p. 455). Methodological inventiveness is a joyful resistance to rigid and regulatory knowledge economies because it allows for fluidity, multiplicity, and new pathways of being and knowing differently to emerge.

In the end, Princes Pearl helps Zog to write a new ending for the same old story. Methodological inventiveness has helped me as a researcher to continually look for new endings, and new beginnings. Kumashiro has reminded me to "learn from the work, but always look beyond it by troubling [my] own authority and the authority of [my] readings and refuse finality" (2000, p. 200). With this in mind, I hope to show how methodological inventiveness helped me look for new, innovative and responsive ways of doing research in my specific context.

Through a playful engagement with the children's book Zog I used this section to create an arts-based narrative of my journey of becoming an educational researcher. Using methodological inventiveness has helped me remember that self-reflexive research is affective, narrative, creative, aesthetic, and collaborative. This understanding helped me grow in my commitment to actively seek new and novel ways of engaging with difficult and complex issues inside and outside the classroom as it relates to education.

\section{Playing with possibilities}

In the previous section I drew on the fictional character Zog to help me tell my story, and also to remember what happened along the way. I have often thought that fictional characters, if we allow them to, show us the things we have forgotten. By sharing this journey, I hope to foreground the excitement and joy of methodological inventiveness alongside the possibilities that it brings to do research with difficult and complex issues in education. I therefore think of methodological inventiveness as a form of post-qualitative inquiry, because it embraces the possibilities that different educational methodologies might open up but resists predetermined and formulaic ways of doing and knowing. As I mention at the start of this article, I embarked on a journey as an educational researcher without knowing much about it. However, looking back I realise that discovery, risk taking, and experimenting with different methods that I enjoy helped me develop into a self-reflexive researcher. In using playfulness and joy I have discovered that for the self-reflexive researcher

having fun seriously matters

and playfully thinking

how to create

gives you new answers

to questions you did not think to ask

Seeing yourself differently

shows you things you did not expect 
on the uncomfortable path we carefully tread stepping between the complex experiences that are woven together shaped into something new like a ball of clay in the hands of a child playfully unexpectedly imaginatively unfolding ...

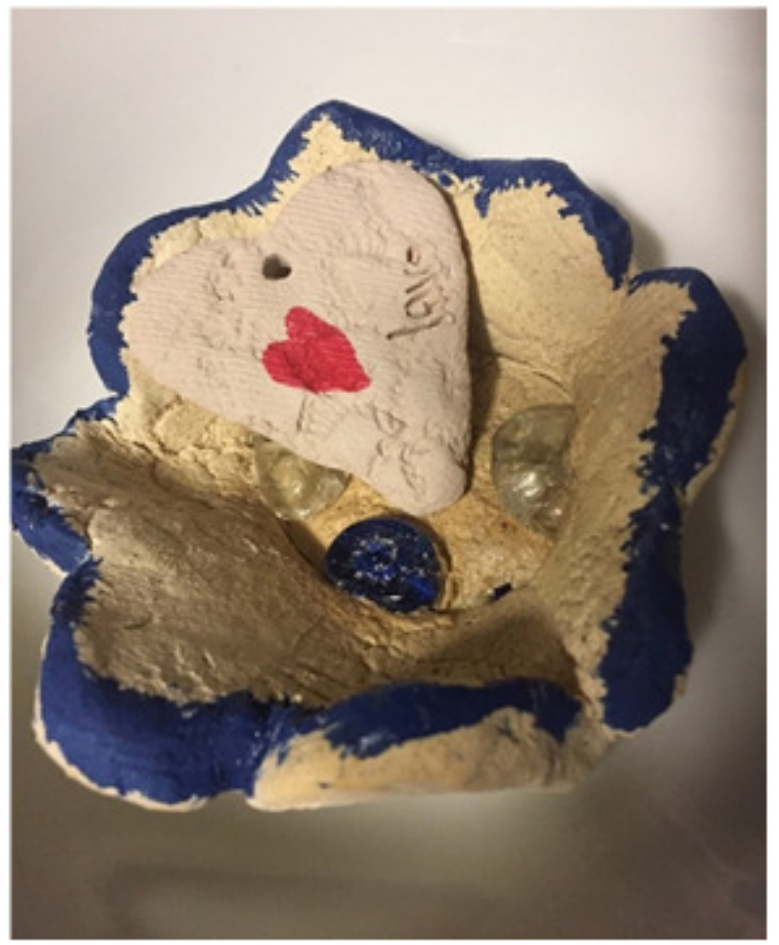

Figure 5: The shape of love, Mirabel Kruger, 2019, clay and paint

... to remind me

that we cannot have justice without love (hooks, 2000)

Love and joy help us make connections

and methodological inventiveness helps us to remember

what was already there

long before

the word methodology even existed

creating, playing, and having fun

through art

made me realise that

to put words on paper

to describe my journey of discovery

and to frame my thoughts

on pieces of coloured paper 


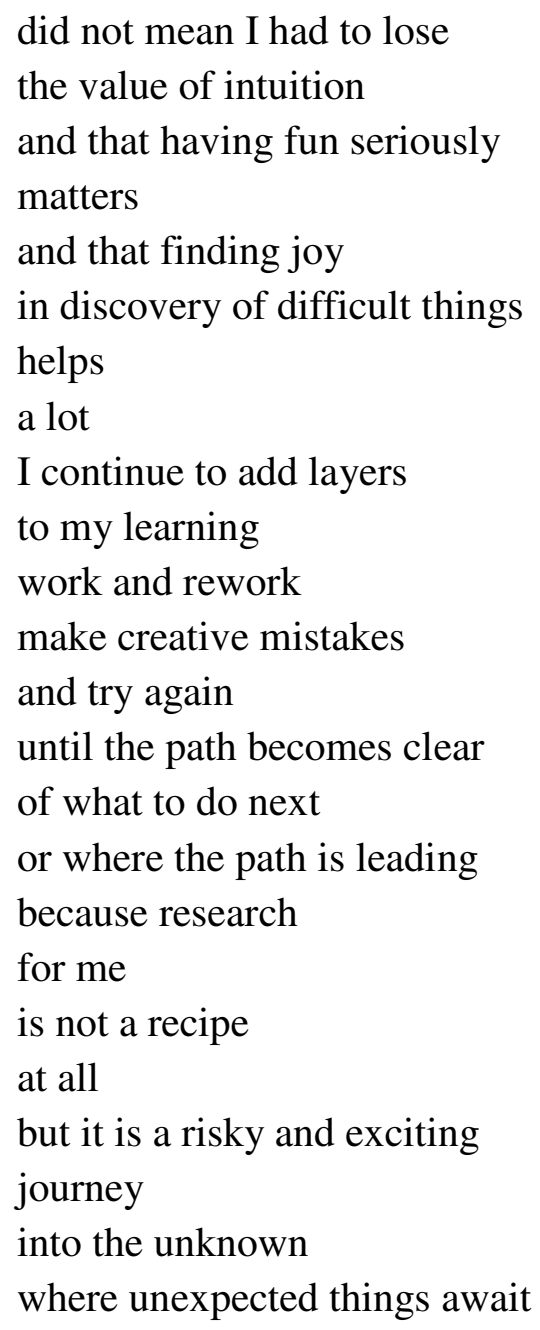

\section{References}

Botha, C. S., \& Rens, J. (2018). Are they really “ready, willing and able?" Exploring reality shock in beginner teachers in South Africa, RSA. South African Journal of Education, $38(3), 1-7$.

Butler, J. (2004). Precarious lives. London, UK: Verso.

Chase, S. E. (2011). Narrative inquiry: Still a field in the making. In N. K. Denzin \& Y. S. Lincoln (Eds.), The SAGE handbook of qualitative research (pp. 421-434). Thousand Oaks, CA: SAGE.

Clandinin, J. D., \& Connelly, M. F. (2000). Narrative Inquiry. Experience and Story in Qualitative Research. San Francisco, CA: Jossy-Bass.

Clough, P. (2002). Narratives and fictions in educational research. Philadelphia, PA: Open Univeristy Press.

Denzin, N. K. (2003). The call to performance. Symbolic Interaction, 26(1), 187-207. 
Donaldson, J., \& Scheffler, A. (2010). Zog. London, UK: Alison Green Books.

Eliastam, J., Müller, J. C., Müller, M., and Trahar, S. (2019). Fictionalisation and research. In In J. C. Müller, J. Eliastam, \& S. Trahar (Eds.), Unfolding narratives of ubuntu in Southern Africa (pp. 12-28). New York, NY: Routledge.

Franzak, J. K. (2002). Developing a teacher identity: The impact of critical friends practice on the student teacher. English Education, 34(4), 258-280.

Gannon, S., \& Conick, M. (2019). Collective biography as a feminist methdology. In G. Grimmins, (Ed.), Strategies of resisting sexism in the academy (pp. 207-224). Cham, $\mathrm{CH}$ : Palgrave Macmillan.

Gannon, S., Taylor, B., Adams, G., Donaghue, H., Hannam-Swain, S., Harris-Evans, J., . . . Moore, P. (2019). "Working on a rocky shore": Micro-moments of positive affect in academic work. Emotion, Space and Society, 31, 48-55.

hooks, b. (2000). All about love: New visions. New York, NY: William Morrow.

Ingold, T. (2011). Being alive. Essays on movement, knowledge and description. New York, NY: Routledge.

Jansen, J. J. (2017). Sense and nonsense in the decolonisation of curriculum. In J. J. Jansen (Ed.), As by fire. The end of the South African university (pp. 153-171). Cape Town, RSA: Tafelberg.

Knowles, C. (2014). Vulnerability: Self-study's contribution to social justice education. Perspectives in Education, 32(2), 89-101.

Kumashiro, K. (2000). Toward a theory of anti-oppressive education. Review of Educational Research, 70(1), 25-53.

Lahman, M. K., Taylor, C. M., Beddes, L. A., Blount, I. D., Bontempo, K. A., Coon, D. J., . . . Motter, B. (2019). Research falling out of colorful pages onto paper: Collage inquiry. Qualitative Inquiry, 26(3-4), 262-270.

Lawrence, R. L. (2019). Tales from the butterfly cafe: Imagined dialogues with fictional characters for research and practice. In C. Jarvis \& P. Gouthro (Eds.), Professional education with fiction media (pp. 107-128). Cham, CH: Palgrave Mcmillan.

le Grange, L. (2018). What is (post) qualitative research? South African Journal of Higher Education, 32(5), 1-14.

Leavy, P. (2009). Method meets art: Arts-based research practice. New York, NY: The Guilford Press. 
Leavy, P. (2013 ). Fiction as research practice: Short stories, novellas and novels. Walnut Creek, CA: Left Coast Press.

Mbembe, A. (2016). Decolonizing the university: New directions. Arts \& Humanities in Higher Education, 15(1), 29-45.

Meskin, T., \& van der Walt, T. (2014). The director's "I": Theatre, self and self-study. Perspectives in Education, 32(2), 54-68.

Mitchell, C., Strong-Wilson, T., Pithouse, K., \& Allnutt, S. (2011). Memory and pedagogy. New York, NY: Routledge.

Müller, M. (2016). A collaborative self-study of educators working towards anti-oppressive practice in higher education (Unpublished doctoral dissertation). Univeristy of the Free State, Bloemfontein, RSA.

Müller, M., Collins, D. M., Matshepo E. N., Mofokeng, T., Lephatsoe, N., \& Mouton, R. (2018). Working toward a socially just curriculum in South Africa: A collaborative autobiographical narrative inquiry. Journal of Eucation, 73, 85-101.

Pithouse, K., Mitchell, C., \& Moletsane, R. (2009). Making connections. New York, NY: Peter Lang.

Pithouse-Morgan, K., Coia, L., Taylor, M., \& Samaras, A. (2016). Exploring methodlogical inventivness through collective artful self-sudy research. LEARNing Landscapes, $9(2), 443-460$.

Richards, J., \& Haberlin, S. (2019). Exploring critical events in an inaugural arts-based research class through ethnographic mapping and poetry-enriched narrative sketches. The Qualitative Report, 24(8), 1930-1945.

Richardson, L., \& St. Pierre, E. A. (2005). Writing: A method of inquiry. In N. K. Denzin \& Y. Lincoln (Eds.), The SAGE handbook of qualitative research (pp. 959-978). Thousand Oaks, CA: SAGE.

St. Pierre, E. A. (2013). The appearance of data. Cultural Studies $\leftrightarrow$ Critical Methodologies, 13(4), 223-227.

St. Pierre, E. A. (2019). Post qualitative inquiry, the refusal of method, and the risk of the new. Qualitative Inquiry, 1-7. Advance online publication. https://doi.org $0.1177 / 1077800419863005$

Young, B. (2007). The complexity of identity 'Who am I'. In M. Adams, L. Bell, \& P. Griffin (Eds.), Teaching for diversity and social justice (pp. 9-14). New York, NY: Routledge. 